Article

\title{
Over 20-Year Follow-up of Patients with Hepatic Glycogen Storage Diseases: Single-Center Experience
}

\author{
Edyta Szymańska ${ }^{1,+}$, Patryk Lipiński ${ }^{2,+}{ }^{\circledR}$, Dariusz Rokicki ${ }^{2}$, Janusz Książyk ${ }^{2}{ }^{(1)}$ and \\ Anna Tylki-Szymańska ${ }^{2, *}$ \\ 1 Department of Gastroenterology, Hepatology, Feeding Disorders and Pediatrics, Children's Memorial Health \\ Institute, 04-730 Warsaw, Poland; edyta.szymanska@onet.com.pl \\ 2 Department of Pediatrics, Nutrition and Metabolic Diseases, Children's Memorial Health Institute, \\ 04-730 Warsaw, Poland; p.lipinski@ipczd.pl (P.L.); d.rokicki@ipczd.pl (D.R.); j.ksiazyk@ipczd.pl (J.K.) \\ * Correspondence: a.tylki@ipczd.pl; Tel.: +48-22-815-74-94 \\ + These authors contributed equally to this work.
}

Received: 23 April 2020; Accepted: 11 May 2020; Published: 13 May 2020

\begin{abstract}
Background: The published data on the long-term outcomes of glycogen storage disease (GSD) patients is sparse in the literature. The aim of this study was to analyze the long-term (over 20 years) follow-up of patients with hepatic types of GSD-I, III, VI, and IX-from childhood to adulthood, managed by one referral center. Patients and methods: Thirty adult patients with hepatic GSD were included in the study. A retrospective chart review of patients' medical records has been performed. Results: During the long-term follow-up, the most frequent complications observed in a group of 14 GSD I patients were nephropathy with blood hypertension (10/14), hyperuricemia (8/14), and development of hepatocellular adenomas (HCA; 5/14). All individuals but four presented with normal height. Two patients with GSD Ib suffered from inflammatory bowel disease (IBD). Nine (64\%) GSD I patients were in balanced metabolic condition at the age of 18. Regarding GSD III/VI/IX, the most frequent complication was short stature observed in 5 out of 16 patients. All patients but one with GSD VI were in balanced metabolic condition at the age of 18. Conclusion: The long-term outcomes of patients with GSD depend mainly on proper (adjusted to each type of GSD) dietary management and patient compliance. However, in GSD type I, even proper management does not eliminate all long-term complications in adulthood.
\end{abstract}

Keywords: glycogen storage disease; long-term follow-up; disease outcome; hypertension; hepatocellular adenoma; short stature

\section{Introduction}

Glycogen storage disorders (GSD) are rare inborn errors of carbohydrate metabolism; there are eight liver types: Ia and b, III, IV, VI, IX, XI, and 0, respectively. Each type is a distinct entity with a distinct metabolic block (deficiency of a different enzyme).

\subsection{GSD Type I}

GSD type I is caused by the deficiency of glucose-6-phosphase (G6P in subtype Ia) or G6P transporter/translocase through the mitochondrial membrane (G6PT in subtype Ib) [1]. That is a key enzyme in the gluconeogenesis and glycogenolysis processes, and therefore GSD I is the most severe type. Decreased/lack of G6P activity leads to accumulation of glycogen and fats within hepatocytes, kidneys and erythrocytes. The early-onset symptoms include hepatomegaly and hypoglycemia with increased lactate (LA) levels, which occurs soon after the meal (within 3-4 h). Patients may be of short stature. Typical biochemical abnormalities include hyperlipidermia and hyperuricemia [2]. Patients 
with subtype Ib present with neutropenia, which causes recurrent bacterial infections [3], and thus they are treated with granulocytes colony stimulating factor (G-CSF). Since G6P is an enzyme present not only in the liver, but also in the kidneys, blood hypertension and nephropathy may occur. Vitamin D deficiency and osteopenia/osteoporosis are also common complications of GSD I [4,5].

Since maintaining a stable blood glucose concentration is a goal of the therapy, uncooked cornstarch (CS) is a mainstay of nutritional treatment in type I, in which hypoglycemia occurs faster than in types III/VI/IX, and these episodes are more severe because ketogenesis has not the time to be triggered, the fasting tolerance is being too short [2]. However, it seems that management with diet does not eliminate late-onset renal damage, nor subsequent renal failure, nephrolithiasis, and development of hepatocellular adenomas (HCA); and an increased risk for HCC (Hepatocellular carcinoma) still remains as a long-term complication, especially in GSD type I [6,7].

\subsection{GSD Type III, VI, and IX}

These are so-called ketotic types since ketone production during hypoglycemia is higher than in type I. GSD type III is caused by decreased/lack of activity of debranching enzyme; type VI is caused by glycogen phosphorylase inactivity; and in type IX phosphorylase kinase (pK) is dysfunctional. These GSDs are characterized by hepatomegaly and episodes of hypoglycemia, which are less severe than in type I and their frequency decreases with age $[8,9]$.

In type III, cardiomegaly and cardiomyopathy may occur, and creatine kinase (CK) level is usually increased. Type VI is clinically the mildest one, and some adults are almost asymptomatic. GSD IX includes four subtypes and the most common one is an X-linked form (GSD IX-alpha), accounting for $75 \%$ of all cases.

The symptoms include hepatomegaly, mild psychomotor retardation, short stature, and mild muscle hypotonia. The patients' symptoms become milder with age [10]. In GSD III/VI/IX, a high-protein diet is provided; GSD type III patients often need cornstach when they are children [11]. Since type IIIa and IX-alpha present also with muscular manifestations (myopathy, cardiomyopathy), the high protein diet is the basis of dietary management [12].

\subsection{Diagnosis}

The diagnosis of GSD is established based on the patient's clinical phenotype and the results of biochemical analyses, and is finally confirmed (if available) by molecular analyses.

Typical symptoms common for all GSD types but one (type 0 ) are hepatomegaly (not present in type 0 ), hypoglycemia, short stature, and frequently, due to the dietary management with CS-obesity (typically in type I) $[3,8,9]$.

Biochemical abnormalities include hypoglycemia, hyperlipidermia, hyperuricemia (in type I), elevated serum transaminases, increased LA level (type I), increased CK level (type III, IX), and neutropenia in type $\mathrm{Ib}[2,10]$.

Prolonged fasting tests are not usually performed and are not useful (and even dangerous) for differentiating between type I and type III. Enzymatic assays are no longer performed, and they have been replaced by molecular analyses.

Furthermore, abdominal ultrasonography and transient elastography by FibroScan (if available) are performed to assess hepatomegaly and nephromegaly; the liver's echostructure and its steatosis/fibrosis state; and the presence of any liver lesions.

Various diagnostic tools are used to detect GSD's complications. In our center, anthropometric assessment and calorimetry are available and are performed to analyze each patients' nutritional status. Densytometry is provided to assess each patient's skeletal condition. In order to detect HCA/HCC, both CT and MRI scans are used, and AFP (Alpha-fetoprotein) level is regularly checked. 


\subsection{Medical Management}

The mainstay of medical management in GSD is to prevent episodes of hypoglycemia and to maintain stable blood glucose level; therefore, dietary treatment is the basic therapy. Specific dietary interventions for each type are mentioned above. Nonetheless, the disease complications, if present, need some additional management, including allopurinol in patients who develop hyperuricemia, ACE-inhibitors in patients with blood hypertension, 5-ASA in GSD Ib patients who develop inflammatory bowel disease (IBD), G-CSF in GSD $\mathrm{Ib}$ patients with neutropenia, and hypolipemic agents in patients with hyperlipidemia.

The aim of this study was to analyze the long-term outcomes (over 20 years) of patients with hepatic types of GSD-I, III, VI, and IX-from childhood to adulthood, managed by one referral center. This is a unique opportunity, since our group is large for a rare disease, and the monitoring and follow-up have been provided by one site only.

\section{Patients and Methods}

Thirty adult patients with hepatic GSDs, including 8 with GSD Ia, 6 with GSD Ib, 8 with GSD III, 7 with GSD VI, and 1 with GSD IX, were included in the study. The observation period was between 1982 and 2018. Among 30 patients diagnosed and treated since infancy, 25 (83\%) have still followed-up with and been monitored by our Institute (Children's Memorial Health Institute-CHMI) within the outpatient clinic since the age of 18.

Based on medical charts of patients, the following parameters were analyzed: signs and symptoms at time of diagnosis; age at diagnosis; dietary and medical management; anthropological and biochemical parameters, including body mass index (BMI) and serum aspartate aminotransferase (AST), serum alanine aminotransferase (ALT), serum triglyceride (TG), serum total cholesterol (TC), lactate (LA), and uric acid (UA) levels; and long-term complications.

Ethical approval (Code 167/KD/2014, date 29/October/2014) of the study protocol was obtained from the Children's Memorial Health Institute Bioethical Committee, Warsaw, Poland.

\section{Results}

\subsection{GSD Type Ia and $I b$}

There were 14 patients with GSD type I, including eight individuals with type Ia and six with type $\mathrm{Ib}$. The majority (5/8) of patients with type Ia were diagnosed within their first year of life (mean age: 1.5 years old, age range: 5 months old to 4 years old), and the mean age of GSD Ib diagnosis was approximately 3 (age range: 6 months old to 7 years old) (Table 1 ).

All patients had dietary management (individually assessed energy requirements and proportions of diet components) introduced once the diagnosis was established, and CS consumption commenced since the age of 6-8 months (to prevent diarrhea when the intestinal microbiota is not fully developed). Only one GSD Ia patient had nightly glucose infusions for his first year of medical management, which were then substituted with CS.

Over half of the patients (9/14) were in balanced metabolic condition at the age of 18 (Table 1). Serum AST was elevated in 5/6 GSD Ia patients, and ALT was elevated in three of them. All GSD Ia patients present with elevated TC and TG levels. Serum lactate was elevated in all GSD Ia patients, and uric acid in $3 / 8$ patients.

Serum AST and ALT were within normal laboratory values in all GSD Ib patients. Elevated TG levels were present in $3 / 5$ patients, and TC levels were within normal values in all of them. Serum lactate was elevated in $3 / 4$ patients, and uric acid in $1 / 5$ patients. 
Table 1. Detailed characteristics of adult patients with GSD type I included in the study $(n=14)$.

\begin{tabular}{|c|c|c|c|c|c|c|c|c|c|c|}
\hline \multicolumn{11}{|c|}{ GSD Ia } \\
\hline \multirow{2}{*}{$\begin{array}{l}\text { Patient's } \\
\text { Number } \\
\text { and Gender }\end{array}$} & \multirow{2}{*}{$\begin{array}{c}\text { Age at Diagnosis/ } \\
\text { Current Age } \\
\text { (m-Months, y-Years) }\end{array}$} & \multirow[b]{2}{*}{ Diet } & \multicolumn{6}{|c|}{ Laboratory Results at 18 y } & \multirow{2}{*}{$\begin{array}{c}\text { Complications and Age of } \\
\text { Appearance }\end{array}$} & \multirow[b]{2}{*}{$\begin{array}{c}\text { Metabolic Homeostasis at } \\
\text { Present }\end{array}$} \\
\hline & & & $\begin{array}{c}\text { BMI } \\
\left(\mathrm{kg} / \mathrm{m}^{2}\right)\end{array}$ & $\begin{array}{c}\text { ALT/AST } \\
\text { (U/L) }\end{array}$ & $\begin{array}{c}\mathrm{LA} \\
(\mathrm{mg} / \mathrm{dL})\end{array}$ & $\begin{array}{c}\mathrm{TG} \\
(\mathrm{mg} / \mathrm{dL})\end{array}$ & $\begin{array}{c}\mathrm{TC} \\
(\mathrm{mg} / \mathrm{dL})\end{array}$ & $\begin{array}{c}\mathrm{UA} \\
(\mathrm{mg} / \mathrm{dL})\end{array}$ & & \\
\hline 1. $\mathrm{M}$ & $12 \mathrm{~m} / 46 \mathrm{y}$ & Followed & 23.2 & $36 / 43$ & 76.5 & 2190 & 544 & 7.8 & $\begin{array}{l}\mathrm{HCA} / \mathrm{KS} / \mathrm{HT} / \mathrm{HL} / \mathrm{HU} \text { and } \\
\text { gout; } \\
\text { since adolescence }\end{array}$ & $\begin{array}{l}\text { Moderate } \\
\text { (HL and HT) }\end{array}$ \\
\hline 2. $\mathrm{F}$ & $6 \mathrm{~m} / 19 \mathrm{y}$ & Followed & 23.7 & $21 / 21$ & 65 & 563 & 325 & 5.8 & $\begin{array}{l}\text { IBD/HT/Recurrent nose } \\
\text { bleeding; } \\
\text { since childhood and } \\
\text { adolescence }\end{array}$ & $\begin{array}{l}\text { Moderate } \\
\text { (HL and HT) }\end{array}$ \\
\hline 3. $\mathrm{M}$ & $12 \mathrm{~m} / 25 \mathrm{y}$ & $\begin{array}{c}\text { Followed; } \\
\text { Additional glucose } \\
\text { intake (drinks) }\end{array}$ & N/A & N/A & N/A & N/A & N/A & N/A & N/A & N/A \\
\hline 4. $\mathrm{F}$ & $5 \mathrm{~m} / 24 \mathrm{y}$ & Followed & 23.3 & $42 / 60$ & 40 & 919 & 439 & 5.8 & $\begin{array}{c}\text { HT/HL/M; } \\
\text { Since adolescence and } \\
\text { adulthood }\end{array}$ & $\begin{array}{l}\text { Moderate } \\
\text { (HL and HT) }\end{array}$ \\
\hline 5. F & $3 y / 43 y$ & Followed & 22.6 & $67 / 68$ & 116 & 1470 & 342 & 9.3 & $\begin{array}{c}\mathrm{M} / \mathrm{HCA} / \mathrm{HL} / \mathrm{HU} ; \\
\text { Since adolescence and } \\
\text { adulthood }\end{array}$ & Unbalanced \\
\hline 6. F & $6 \mathrm{~m} / 35 \mathrm{y}$ & Followed & N/A & N/A & N/A & $>1000$ & N/A & N/A & $\begin{array}{c}\mathrm{HCA} / \mathrm{HL} / \mathrm{HT} \\
\text { Since adolescence }\end{array}$ & $\begin{array}{l}\text { Due to improvement in } \\
\text { patient's compliance the } \\
\text { metabolic homeostasis is } \\
\text { stable now/HCA } \\
\text { disappeared }\end{array}$ \\
\hline 7. $\mathrm{M}$ & $4 \mathrm{y} / 43 \mathrm{y}$ & Followed & 22.6 & $62 / 23$ & 81 & 219 & 177 & 8.3 & $\begin{array}{c}\mathrm{RH} / \mathrm{HCA} / \mathrm{HU} ; \\
\text { Since adolescence }\end{array}$ & $\begin{array}{c}\text { Balanced/ } \\
\text { Born a healthy child }\end{array}$ \\
\hline 8. $\mathrm{M}$ & $2 \mathrm{y} / 31 \mathrm{y}$ & Followed & 22.3 & $70 / 42$ & 116 & 723 & 307 & 8.2 & $\begin{array}{c}\text { SS/HU/HL; } \\
\text { Since childhood }\end{array}$ & $\begin{array}{c}\text { Moderate/ } \\
\text { Due to non-compliance } \\
\text { HCA/HT/HU/ } \\
\text { HL developed }\end{array}$ \\
\hline
\end{tabular}


Table 1. Cont.

\begin{tabular}{|c|c|c|c|c|c|c|c|c|c|c|}
\hline \multicolumn{11}{|c|}{ GSD Ia } \\
\hline \multirow{2}{*}{$\begin{array}{l}\text { Patient's } \\
\text { Number } \\
\text { and Gender }\end{array}$} & \multirow{2}{*}{$\begin{array}{c}\text { Age at Diagnosis/ } \\
\text { Current Age } \\
\text { (m-Months, y-Years) }\end{array}$} & \multirow[b]{2}{*}{ Diet } & \multicolumn{6}{|c|}{ Laboratory Results at 18 y } & \multirow{2}{*}{$\begin{array}{c}\text { Complications and Age of } \\
\text { Appearance }\end{array}$} & \multirow[b]{2}{*}{$\begin{array}{c}\text { Metabolic Homeostasis at } \\
\text { Present }\end{array}$} \\
\hline & & & $\begin{array}{c}\text { BMI } \\
\left(\mathrm{kg} / \mathrm{m}^{2}\right)\end{array}$ & $\begin{array}{l}\text { ALT/AST } \\
\text { (U/L) }\end{array}$ & $\begin{array}{c}\mathrm{LA} \\
(\mathrm{mg} / \mathrm{dL})\end{array}$ & $\begin{array}{c}\mathrm{TG} \\
(\mathrm{mg} / \mathrm{dL})\end{array}$ & $\begin{array}{c}\mathrm{TC} \\
(\mathrm{mg} / \mathrm{dL})\end{array}$ & $\underset{(\mathrm{mg} / \mathrm{dL})}{\mathrm{UA}}$ & & \\
\hline \multicolumn{11}{|c|}{ GSD Ib } \\
\hline 9. $\mathrm{M}$ & $1.5 \mathrm{y} / 31 \mathrm{y}$ & Followed & N/A & $\mathrm{N} / \mathrm{A}$ & N/A & N/A & N/A & N/A & $\begin{array}{c}\text { IgA-N/HT/Neu (800/uL), } \\
\text { Neupogen introduced since } \\
\text { 13y (AP before that)/ } \\
\text { Since childhood }\end{array}$ & Moderate \\
\hline 10. $\mathrm{M}$ & $10 \mathrm{~m} / 24 \mathrm{y}$ & Followed & N/A & $6 / 11$ & N/A & 52 & 88 & 5.5 & $\begin{array}{l}\text { Neu }(600 / \mathrm{uL}) / \text { Recurrent } \\
\text { mouth and gingival } \\
\text { infections/Sensorineural } \\
\text { hearing loss } \\
\text { (hearing aids)/HT/AP/ } \\
\text { since childhood }\end{array}$ & Balanced \\
\hline 11. F & $6 y / 27 y$ & Followed & 20 & $26 / 26$ & 28 & 259 & 109 & 8 & 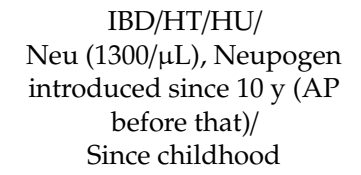 & $\begin{array}{c}\text { Moderate/ } \\
\text { Recurrent IBD flares at } \\
\text { adulthood }\end{array}$ \\
\hline 12. $\mathrm{M}$ & $6 \mathrm{~m} / 26 \mathrm{y}$ & Followed & 17 & $7 / 13$ & 139 & 170 & 78 & 5.3 & 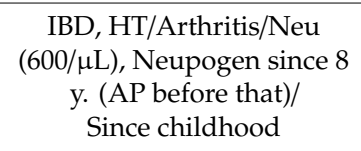 & $\begin{array}{c}\text { Unbalanced/ } \\
\text { Recurrent IBD flares at } \\
\text { adulthood, cannot walk } \\
\text { due to arthritis, depression }\end{array}$ \\
\hline 13. F & $\begin{array}{l}\text { N/A } \\
47 \mathrm{y}\end{array}$ & Followed & N/A & $8 / 22$ & 30 & 193 & 167 & 6.7 & $\begin{array}{l}\text { Recurrent infections due to } \\
\text { Neu, only AP, Neupogen } \\
\text { has never been } \\
\text { administered/ } \\
\text { Since childhood }\end{array}$ & Moderate \\
\hline 14. $\mathrm{F}$ & $7 \mathrm{y} / 40 \mathrm{y}$ & Followed & 39.6 & $29 / 27$ & 8 & 36 & 65 & 6.9 & $\begin{array}{c}\mathrm{KS} / \\
\text { since adolescence }\end{array}$ & $\begin{array}{c}\text { Balanced/ } \\
\text { gave birth to a healthy child }\end{array}$ \\
\hline
\end{tabular}


The majority of GSD I patients have been followed at our Metabolic Outpatient Clinic, where the diet was supervised and biochemical parameters monitored-in most cases both the compliance and laboratory results were satisfactory (Table 1). During the long-term follow-up, the most common complications observed in GSD I patients were nephropathy with blood hypertension (10/14), hyperuricemia (8/14), and development of HCA (5/14). All individuals but four (29\%) were of normal height.

Almost all patients with GSD type I who developed hyperuricemia were given allopurinol to prevent arthritis. We tried to manage hyperlipidemia with dietary interventions; however, if TG level was above $500 \mathrm{mg} / \mathrm{dl}$, which according to literature [13] is associated with significantly increased risk of acute pancreatitis and HCA/HCC development, the patient usually had hypolipemic agents (either fibrates or statins) introduced. Patients with blood hypertension had ACE-inhibitors applied to prevent progression to an end-stage renal disease. The majority of GSD Ib individuals were treated with G-CSF and those who developed IBD had, additionally, 5-ASA agent introduced.

The majority of those complications developed either during childhood or adolescence, although the proper diet had been introduced since each diagnosis had been established. Two women with GSD Ia (patient 4 and 5) had menorrhagia; one gave birth to a healthy child without any complications. One patient with GSD Ib (patient 10) developed hearing problems (sensorineural hearing loss). One GSD Ia patient (patient 2) presented with bleeding problems (excessive epistaxis). Two patients with GSD Ib (patient 11 and 12) suffered from IBD, and patient 12 had arthritis. Both patients had active IBD at the age of 18 and have experienced a lot of flare-ups during adulthood.

\subsection{GSD Type III, VI, IX}

There were 16 patients diagnosed with GSD III/VI/IX: 8, 7, and 1, respectively. In comparison to patients with GSD I, the diagnosis was established later-the mean age at diagnosis was approximately 3 (age range: 4 months old to 8 years old).

All patients but one had balanced metabolic conditions at the age of 18 (Table 2). Serum AST was elevated in 4/8 GSD III patients, in 1/4 GSD VI patients, and in 1 GSD IX patient. Serum ALT was elevated in 3/8 GSD III patients; all GSD VI and GSD IX patients had normal ALT levels. Elevated TC levels were present in 7/14 patients:-4/7 with GSD III, 1/4 with GSD VI, and 1 patient with GSD IX. Elevated TG levels were present in 5/14 patients-3/7 with GSD III and 2/4 with GSD VI. Serum lactate was checked only in one patient (patient 11), and it was within normal values. Uric acid was checked in only 5/14 patients; in all of them it was normal. CK activity was found to be elevated in 3/8 GSD III patients.

During the long-term follow-up the most common complication in these patients was short stature, present in 5/16 patients; in three of them it was a considerably short stature ( $>2 \mathrm{SD} ; 31 \%)$. One patient with type VI (patient 11) developed diabetes mellitus (DM) type 1 at the age of 4 and was treated with insulin. 
Table 2. Detailed characteristics of adult patients with GSD types III/VI/IX included in the study $(n=16)$.

\begin{tabular}{|c|c|c|c|c|c|c|c|c|c|c|}
\hline \multirow{2}{*}{$\begin{array}{l}\text { Patient's } \\
\text { Number } \\
\text { and Gender }\end{array}$} & \multirow{2}{*}{$\begin{array}{c}\text { Age at Diagnosis/ } \\
\text { Current Age } \\
\text { (m-Months, y-Years)) }\end{array}$} & \multirow[b]{2}{*}{ Diet } & \multicolumn{6}{|c|}{ Laboratory Results at 18 y } & \multirow{2}{*}{$\begin{array}{l}\text { Complications and } \\
\text { Other Issues }\end{array}$} & \multirow{2}{*}{$\begin{array}{c}\text { Metabolic } \\
\text { Homeostasis at } \\
\text { Present }\end{array}$} \\
\hline & & & $\begin{array}{c}\text { BMI } \\
\left(\mathrm{kg} / \mathrm{m}^{2}\right)\end{array}$ & $\begin{array}{l}\text { ALT/AST } \\
\text { (U/L) }\end{array}$ & $\begin{array}{c}\text { LA } \\
(\mathrm{mg} / \mathrm{dL})\end{array}$ & $\begin{array}{c}\text { TG } \\
(\mathrm{mg} / \mathrm{dL})\end{array}$ & $\begin{array}{c}\text { TC } \\
(\mathrm{mg} / \mathrm{dL})\end{array}$ & $\underset{(\mathrm{mg} / \mathrm{dL})}{\mathrm{UA}}$ & & \\
\hline \multicolumn{11}{|c|}{ GSD type III } \\
\hline 1. $\mathrm{M}$ & $1.5 \mathrm{y} / 24 \mathrm{y}$ & Followed & 18.5 & $46 / 105$ & N/A & 74 & 153 & 5.4 & $\begin{array}{c}\text { None; } \\
\text { CK normal }\end{array}$ & Balanced \\
\hline 2. $\mathrm{M}$ & $4 y / 25 y$ & Followed & 18.7 & $39 / 22$ & N/A & 81 & 179 & N/A & $\begin{array}{c}\text { None; } \\
\text { CK normal }\end{array}$ & Balanced \\
\hline 3. $\mathrm{M}$ & $3 y / 26 y$ & $\begin{array}{l}\text { High-CH at the } \\
\text { beginning } \\
\text { then GSD III/VI/IX }\end{array}$ & 20.5 & $41 / 29$ & N/A & 103 & 158 & N/A & $\begin{array}{c}\text { None; } \\
\text { CK normal }\end{array}$ & Balanced \\
\hline 4. F & $2 y / 26 y$ & Followed & 22.3 & $21 / 25$ & N/A & 83 & 227 & $\mathrm{~N} / \mathrm{A}$ & $\begin{array}{c}\text { None; } \\
\text { CK elevated (392 U/L) }\end{array}$ & Balanced \\
\hline 5. F & $6 y / 33 y$ & Followed & 24.4 & $36 / 22$ & N/A & N/A & N/A & N/A & $\begin{array}{c}\text { None; } \\
\text { CK normal } \\
\end{array}$ & Balanced \\
\hline 6. F & $10 \mathrm{~m} / 36 \mathrm{y}$ & Followed & 23.2 & $79 / 84$ & N/A & 86 & 206 & 6.6 & $\begin{array}{c}\text { Back pain, fatigue; } \\
\text { CK elevated (1336 U/L) }\end{array}$ & Balanced \\
\hline 7. F & $3 y / 37 y$ & Followed & 24.6 & $64 / 44$ & N/A & 220 & 188 & N/A & $\begin{array}{c}\text { Fatigue; } \\
\text { CK elevated (390 U/L) }\end{array}$ & Balanced \\
\hline 8. $\mathrm{M}$ & $4.5 \mathrm{y} / 32 \mathrm{y}$ & Followed & 22 & $122 / 61$ & N/A & 121 & 178 & N/A & $\begin{array}{c}\text { None; } \\
\text { CK normal } \\
\end{array}$ & Balanced \\
\hline 9. $\mathrm{M}$ & $20 \mathrm{~m} / 31 \mathrm{y}$ & followed & 22.7 & $38 / 21$ & N/A & 118 & 141 & 5.6 & None & Balanced \\
\hline 10. $\mathrm{F}$ & $8 \mathrm{y} / 33 \mathrm{y}$ & Followed & 24 & $34 / 21$ & N/A & 40 & 130 & N/A & None & Balanced \\
\hline 11. M & $2 y / 20 y$ & Followed & 21.2 & $61 / 33$ & 12 & 487 & 303 & 6.6 & $\begin{array}{c}\text { DM type I diagnosed at } \\
4 \mathrm{y}\end{array}$ & $\begin{array}{c}\text { Moderate } \\
\text { compliance/DN } \\
\text { treated with } \\
\text { insulin }\end{array}$ \\
\hline 12. $\mathrm{M}$ & $2 y / 21 y$ & Followed & 16 & $32 / 22$ & N/A & 86 & 121 & 2.4 & None & Balanced \\
\hline 13. $\mathrm{M}$ & 4 m/18 y & Followed & N/A & N/A & N/A & N/A & N/A & N/A & N/A & $\begin{array}{c}\text { Follow-up: } 6 \\
\text { years }\end{array}$ \\
\hline
\end{tabular}


Table 2. Cont.

\begin{tabular}{|c|c|c|c|c|c|c|c|c|c|c|}
\hline \multirow{2}{*}{$\begin{array}{l}\text { Patient's } \\
\text { Number } \\
\text { and Gender }\end{array}$} & \multirow{2}{*}{$\begin{array}{c}\text { Age at Diagnosis/ } \\
\text { Current Age } \\
\text { (m-Months, y-Years)) }\end{array}$} & \multirow[b]{2}{*}{ Diet } & \multicolumn{6}{|c|}{ Laboratory Results at $18 \mathrm{y}$} & \multirow{2}{*}{$\begin{array}{l}\text { Complications and } \\
\text { Other Issues }\end{array}$} & \multirow{2}{*}{$\begin{array}{c}\text { Metabolic } \\
\text { Homeostasis at } \\
\text { Present }\end{array}$} \\
\hline & & & $\begin{array}{c}\text { BMI } \\
\left(\mathrm{kg} / \mathrm{m}^{2}\right)\end{array}$ & $\begin{array}{l}\text { ALT/AST } \\
\text { (U/L) }\end{array}$ & $\begin{array}{c}\text { LA } \\
(\mathrm{mg} / \mathrm{dL})\end{array}$ & $\begin{array}{c}\mathrm{TG} \\
(\mathrm{mg} / \mathrm{dL})\end{array}$ & $\begin{array}{c}\text { TC } \\
(\mathrm{mg} / \mathrm{dL})\end{array}$ & $\begin{array}{c}\mathrm{UA} \\
(\mathrm{mg} / \mathrm{dL})\end{array}$ & & \\
\hline \multicolumn{11}{|c|}{ GSD type III } \\
\hline 14. M & $3.5 \mathrm{y} / 22 \mathrm{y}$ & Followed & N/A & N/A & N/A & N/A & N/A & N/A & N/A & $\begin{array}{l}\text { Follow-up: } 4 \\
\text { years }\end{array}$ \\
\hline 15. M & N/A/18 y & Followed & N/A & N/A & N/A & N/A & N/A & N/A & N/A & $\begin{array}{l}\text { Follow-up: } 8 \\
\text { years }\end{array}$ \\
\hline \multicolumn{11}{|c|}{ GSD type IX } \\
\hline 16. F & $3 y / 33 y$ & Followed & 25.4 & $48 / 32$ & N/A & 91 & 201 & N/A & $\begin{array}{c}\text { HL/ } \\
\text { Episodes of } \\
\text { hypoglycemia in } \\
\text { childhood }\end{array}$ & $\begin{array}{c}\text { Balanced/ } \\
\text { When coming of } \\
\text { age-normal } \\
\text { diet }\end{array}$ \\
\hline
\end{tabular}




\section{Discussion}

The manuscript presents data from a 20-year follow-up of 30 patients with hepatic GSDs. So far, data published on the long-term outcomes of hepatic GSD patients is sparse. According to the natural course of GSD I, complications develop with time (the older the patient, the more complications that may occur), and include short stature, renal disorders (glomerular hyperfiltration, microalbuminuria, proteinuria, proximal and/or distal tubules dysfunction, and nephrolithiasis), and increased risk for HCA and HCC development [13-15]. Neutropenia and neutrophils dysfunction predispose to recurrent bacterial infections and development of IBD in GSD Ib. Patients with GSD Ia have the highest risk of HCA development, and that is rarely observed in GSD III/VI/IX [7]. Childhood hepatic symptoms in GSD III/VI/IX tend to become less severe with age, however (up to $12-15 \%$ of adults develop liver fibrosis and cirrhosis) [10].

In our cohort, all patients had proper dietary management (CS in type I, and high protein diet in types III/VI/IX) introduced as soon as the diagnosis of GSD was established. In GSD I patients, CS was introduced at the age of at least 6 months old to prevent diarrhea. Patient compliance was generally satisfactory. Moreover, all of them closely and regularly followed-up, even as adults. Due to that, the patients' adherence improved (they are taught how to manage the diet and control themselves), and by transition (at the age of 18 when pediatric healthcare can no longer be provided, and internal/adult medicine care is delivered) the vast majority of them had balanced metabolic homeostasis. Such nutritional management prevents hypoglycemia, and thus leads to normalization of biochemical markers (levels of TC and TG; liver function tests-AST and ALT; and uric and lactic acid levels) [16].

In our study, nephropathy with hypertension was the most common complication in GSD I patients. The European study for GSD reported in 2002 that all GSD Ia patients developed microalbuminuria or proteinuria by 24 years of age [17]. Once microalbuminuria developed, treatment with ACE-inhibitors was introduced to prevent progression to end-stage renal disease. No patient in our cohort developed the end-stage renal disease.

In the reported cohort, HCA was diagnosed in five patients with GSD Ia and was one of the most common complications in these patients. In all of those patients, they developed it at adolescence, and it was associated with high serum levels of TG $(>500 \mathrm{mg} / \mathrm{dL})$, which is consistent with the literature. HCA formation was one of the first complications reported in GSD type I, but also in type III. Initial studies on GSD type I adults have demonstrated that HCA developed in over $70 \%$ of those patients [18]. The lesions typically occurred during puberty, and malignant transformation risk has been observed. Wang et al. have demonstrated that patients achieving TG concentrations under $500 \mathrm{mg} / \mathrm{dL}$ have a significantly lower rate of HCA formation [13]. Recently, Beegle et al. have reported that regression of HCA identified with both ultrasound and magnetic resonance imaging (MRI) could occur with improvement in metabolic homeostasis [19]. Not only did adenomas regress with good control, but six of nine patients with serial MRI scans had complete disappearance of lesions after a mean of 4.8 years. One of our female patients with GSD Ia with multiple HCA (Patient 6) has confirmed this observation. Once she improved her compliance with the proper diet and CS intake as an adult, her biochemical markers, including TG level, normalized; she achieved balanced metabolic homeostasis and the lesion within her liver disappeared. Malignant transformations of adenomas have never been observed in our group.

One GSD Ia patient presented bleeding problems (excessive epistaxis), which may occur in GSD type I. The impaired coagulation in type I GSD is due to dysfunctional platelets function.

Inflammatory bowel disease (IBD) due to neutropenia and impaired neutrophils function is a common complication in GSD $\mathrm{Ib}$ [20]. The treatment consists of recombinant human granulocyte-colony-stimulating factor (G-CSF), 5-aminosalicylates (ASA), probiotics, and also high dose of vitamin E. In our group, two GSD Ib siblings developed IBD [21]. One of them present with severe cases of bowel disease and arthritis. Both of them have been treated with G-CSF and 5-ASA. Due to lack of proper adult gastroenterological care, their IBD is poorly controlled now. The issue of 
transition is crucial and very difficult. Although we follow-up on our patients from a metabolic point of view, finding other specialists (gastroenterologists, nephrologists) who would like to treat adult metabolic patients is challenging.

The summary of GSD Ia's outcome in adults by Weinstein et al. has demonstrated that complications in GSD Ia can be delayed or prevented with a properly balanced diet [22]. Our results and observations are consistent with those presented by Weinstein et al.

Short stature was observed both in type I and in ketotic types, but it was not as a common complication as we may expect, which only confirmed the proper management of these patients by our site.

The important, although rather obvious observation, is that there are significant differences in both short and long-term complications and outcomes between GSD type I and types III/VI/IX. In our group, no patient with type IIIa developed cardiomyopathy, and the only significant complication in these patients was short stature. Peripheral myopathy may occur in GSD III. Although few patients in our group had increased CPK levels, none of them developed miopatic disorders. Patients with GSD III with normal CPK levels were almost asymptomatic.

The majority of individuals with ketotic GSD types, especially with type VI, were asymptomatic, and they did not even consider themselves to be ill when becoming adults. However, most patients followed their diets once educated at infancy; they stuck to the management they got used to, unlike patients with type I. Although the proper diet was introduced, some complications could not be prevented. In our cohort, the majority of GSD I complications developed either during childhood or adolescence. In some cases, it was due to unsatisfied compliance, but in the majority of the patients it was due to the natural course of the disease. This observation demonstrates that type I is much more severe than types III/VI/IX, and unlike them, diet, though it improves the outcome, does not eliminate some complications.

The advantages of our work are a significant number of patients, long-term follow-up, and proper, up-to-date clinical management provided by a single-referral center.

\section{Conclusions}

1. Long-term outcomes of patients with GSD depend mainly on proper (adjusted to each type of GSD) dietary management and patient compliance. However, in GSD type I, even proper management does not eliminate all long-term complications in adulthood.

2. Nephropathy with hypertension was the most common complication in our cohort of GSD I patients.

3. HCA was diagnosed in 5 out of 14 patients with GSD Ia, and it was one of the most common complications in these patients, associated with high levels of serum TG (>500 mg/dL).

4. Regarding GSD III/VI/IX, the quite common complication was short stature, present in 5/16 patients. All patients but one with type VI were in balanced metabolic condition at the age of 18 .

Author Contributions: Project administration, A.T.-S.; Supervision, D.R., J.K. and A.T.-S.; Writing-original draft, P.L. and E.S.; Writing-review \& editing, P.L., E.S. and A.T.-S. All authors have read and agree to the published version of the manuscript.

Funding: This research received no external funding.

Conflicts of Interest: The authors declare no conflict of interest.

\section{References}

1. Chou, J.Y.; Matern, D.; Mansfield, B.C.; Chen, Y.T. Type I glycogen storage diseases: Disorders of the glucose-6-phosphatase complex. Curr. Mol. Med. 2002, 2, 121-143. [CrossRef] [PubMed]

2. Kishnani, P.S.; Austin, S.L.; Abdenur, J.E.; Arn, P.; Bali, D.S.; Boney, A.; Chung, W.K.; Dagli, A.I.; Dale, D.; Koeberl, D.; et al. Diagnosis and management of glycogen storage disease type I: A practice guideline of the American College of Medical Genetics and Genomics. Genet. Med. 2014, 16, e1. [CrossRef] [PubMed] 
3. Dieckgraefe, B.K.; Korzenik, J.R.; Husain, A.; Dieruf, L. Association of glycogen storage disease $1 \mathrm{~b}$ and Crohn disease: Results of a North American survey. Eur. J. Pediatr. 2002, 161, 88-92. [CrossRef]

4. Rake, J.P.; Visser, G.; Huismans, D. Bone mineral density in children, adolescents and adults with glycogen storage disease type Ia: A cross-sectional and longitudinal study. J. Inherit. Metab. Dis. 2003, 26, 371-384. [CrossRef] [PubMed]

5. Banugaria, S.G.; Austin, S.L.; Boney, A. Hypovitaminosis D in glycogen storage disease type I. Mol. Genet. Metab. 2010, 99, 434-437. [CrossRef]

6. Labrune, P.; Trioche, P.; Duvaltier, I.; Chevalier, P.; Odievre, M. Hepatocellular adenomas in glycogen storage disease type I and III: A series of 43 patientsand review of the literature. J. Pediatr. Gastroenterol. Nutr. 1997, 24, 276-279. [CrossRef]

7. Raghuveer, T.S.; Gardg, U. Inborn errors of metabolism in infancy and early childhood: An update. Am. Fam. Phys. 2006, 73, 1981-1990.

8. Lucchiari, S.; Fogh, I.; Prelle, A. Clinical and genetic variability of glycogen storage disease type IIIa: Seven novel AGL gene mutations in the Mediterranean area. Am. J. Med. Genet. 2002, 109, 183-189. [CrossRef]

9. Roscher, A.; Patel, J.; Hewson, S. The natural history of glycogen storage disease types VI and IX: Long-term outcome from the largest metabolic center in Canada. Mol. Genet. Metab. 2014, 113, 171-176. [CrossRef]

10. Beauchamp, N.J.; Dalton, A.; Ramaswami, U. Glycogen storage disease type IX: High variability in clinical phenotype. Mol. Genet. Metab. 2007, 92, 88-99. [CrossRef]

11. Derks, T.G.; Smit, G.P. Dietary management in glycogen storage disease type III: What is the evidence? J. Inherit. Metab. Dis. 2015, 38, 545-550. [CrossRef] [PubMed]

12. Sentner, C.P.; Hoogeveen, I.J.; Weinstein, D.A.; Santer, R.; Murphy, E.; McKiernan, P.J.; Steuerwald, U.; Beauchamp, N.J.; Taybert, J.; Laforêt, P.; et al. Glycogen storage disease type III: Diagnosis, genotype, management, clinical course and outcome. J. Inherit. Metab. Dis. 2016, 39, 697-704. [CrossRef] [PubMed]

13. Wang, D.Q.; Fiske, L.M.; Carreras, C.T.; Weinstein, D.A. Natural history of hepatocellular adenoma formation in glycogen storage disease type I. J. Pediatr. 2011, 159, 442-446. [CrossRef]

14. Chen, M.A.; Weinstein, D.A. Glycogen storage diseases: Diagnosis, treatment, and outcome. Transl. Sci. Rare Disease 2016, 1, 45-72. [CrossRef]

15. Melis, D.; Cozzolino, M.; Minopoli, G.; Balivo, F.; Parini, R.; Rigoldi, M.; Paci, S.; Dionisi-Vici, C.; Burlina, A.; Andria, G.; et al. Progression of renal damage in glycogen storage disease Type I is associated to hyperlipidemia: A multicenter prospective Italian study. J. Pediatr. 2015, 166, 1079-1082. [CrossRef]

16. Smit, G.P.; Fernandes, J.; Leonard, J.V.; Matthews, E.E.; Moses, S.W.; Odievre, M.; Ullrich, K. The long-term outcome of patients with glycogen storage diseases. J. Inherit. Metab. Dis. 1990, 13, 411-418. [CrossRef]

17. Rake, J.P.; Visser, G.; Labrune, P.; Leonard, J.V.; Ullrich, K.; Smit, G.P. Glycogen storage disease type I: Diagnosis, management, clinical course and outcome. Results of the European Study on Glycogen Storage Disease Type I (ESGSD I). Eur. J. Pediatr. 2002, 161, 120-123. [CrossRef]

18. Lee, P.J. Glycogen storage disease type I: Pathophysiology of liver adenomas. Eur. J. Pediatr. 2002, 161, 46-49. [CrossRef]

19. Beegle, R.D.; Brown, L.M.; Weinstein, D.A. Regression of hepatocellular adenomas with strict dietary therapy in patients with glycogen storage disease type I. JIMD Rep. 2015, 18, $23-32$.

20. Glasser, C.L.; Picoraro, J.A.; Jain, P.; Kinberg, S.; Rustia, E.; Gross Margolis, K.; Anyane-Yeboa, K.; Iglesias, A.D.; Green, N.S. Phenotypic heterogeneity of neutropenia and gastrointestinal illness associated with G6PC3 founder mutation. J. Pediatr. Hematol. Oncol. 2016, 38, 243-247. [CrossRef]

21. Melis, D.; Minopoli, G.; Balivo, F.; Marcolongo, P.; Parini, R.; Paci, S.; Dionisi-Vici, C.; Della Casa, R.; Benedetti, A.; Andria, G.; et al. Improves Clinical outcome of patients affected by glycogen storage disease Type Ib. JIMD Rep. 2016, 25, 39-45. [PubMed]

22. Dambska, M.; Labrador, E.B.; Kuo, C.L.; Weinstein, D.A. Prevention of complications in glycogen storage disease type Ia with optimization of metabolic control. Pediatr. Diabetes 2017, 5, 327-331. [CrossRef] [PubMed]

(C) 2020 by the authors. Licensee MDPI, Basel, Switzerland. This article is an open access article distributed under the terms and conditions of the Creative Commons Attribution (CC BY) license (http://creativecommons.org/licenses/by/4.0/). 